\title{
Does Reconciliation Need Truth? On the Legal Production of the Visibility of the Past* Riccardo Baldissone
}

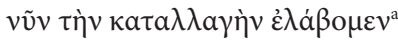

A truth that's told with bad intent / Beats all the lies you can invent ${ }^{\mathrm{b}}$

My work is not about $x \times x \times x \times x$ it is after $x \times x \times x \times x^{c}$

* I would like to thank Doris Pichler and Silke Panse, who introduced me to the work of Milo Rau and Joshua Oppenheimer respectively; and an anonymous reviewer, who rightly claimed more visibility for visibility.

a $[N]$ yn tèn katallagèn elabomen, now we have received reconciliation, in Paul, Romans 5.11. Katallagèn originally means change: in the late fifth century BCE it is first attested with the sense of change from enmity to friendship, that is reconciliation, for example in Aristophanes, Birds 1588.

b William Blake, 'Auguries of Innocence' 53-54, in The Complete Poetry and Prose of William Blake, ed. D. V. Erdman (Berkeley: University of California Press, 2008), 491.

c Christian Boltanski's correction of his written interview: the twice deleted word is Holocaust. In Christian Boltanski, 'An Interview with Georgia Marsh', in Reconstitution, Exhibit Catalogue, Christian Boltanski (London: Whitechapel Art Gallery, 1990), 10. 
In the first chapter of Ulysses, Stephen Dedalus, probably mindful of Laforgue, ${ }^{1}$ complains that history is a nightmare from which he is trying to awake. ${ }^{2}$ Stephen, inasmuch as he is the younger alter ego of James Joyce, shares with him the burden of the past as a representation that is frozen and glorified by academies and museums.

Contemporary Italian Futurists feel similarly oppressed by the load of the glorious but cumbersome Classical and Italian artistic legacy. They react to the canon of art by contrasting the static representation of things by traditional painting and statuary with their dynamic work: in particular, they attempt to visually capture motion as a compresence of subsequent images of a moving object on the same canvas, ${ }^{3}$ as a multiplicity of forms in the same statue, as a visual rendering of sounds with written words, and as a displacement of words and even letters on the written page. ${ }^{4}$

The Futurists claim the power of visual means to operate a reconstruction not only of the world, but, following their taste for hyperbole, of the entire universe. ${ }^{5}$ With the

1 'L'historie est un vieux cauchemar bariolé qui ne se doute pas que les meilleures plaisanteries sont les plus courtes,' History is an old gaudy nightmare who does not suspect that the best jokes are the shortest. In Jules Laforgue, Mélanges Posthumes (Paris: Mercure de France, 1903), 279.

2 James Joyce, Ulysses (Oxford: Oxford University Press, 2008), 34.

3 ' $[U] n$ cavallo in corsa non ha quattro gambe [sic]: ne ha venti, a running horse has not four legs, but twenty. In Umberto Boccioni et al., Pittura Futurista. Il Manifesto Tecnico [Futurist Painting. The Technical Manifesto] (Milano: Uffici di Poesia, 1910).

${ }^{4}$ See Filippo Marinetti, Zang Tumb Tumb (Milano: Edizioni Futuriste di Poesia, 1914). By striving to express 'the dynamic sensation itself, the futurists actually also provide us with a more dynamic rendering of the past.

5 See Giacomo Balla and Fortunato Depero, Ricostruzione futurista dell'universo [Futurist Reconstruction of the Universe] (Milano: Direzione del Movimento Futurista, 1915). 
Futurist Manifestos, for the first time artists claim their share in ideological leadership inasmuch as they are artists. Moreover, the Futurists' insistence on the political relevance of vision renews the millennial tradition of disputes on the use of images.

In the Christian world, the issue of the public role of images is first raised in the eighth century by Byzantine iconoclasm, and it is then rekindled in the sixteenth century during the Reformation. However, these debates focus on the use of images tout-court, whilst the Futurists are rather concerned with the specific quality of images as a contribution to a global transformation of reality.

Though 'painters always showed us things and persons placed before us, ${ }^{3}$ the Futurists contend that objects and people actually compenetrate each other, because 'motion and light destroy the materiality of bodies ${ }^{7}$ : hence, the new art is aimed not at reproducing but at reinventing reality. To this end, it also relies on the dynamism of the new mechanical production, and even on the destructive power of war.

And yet, after the technology-enhanced disasters of the two world conflicts, and the double industrial annihilation of human lives by concentration camps and aerial bombing, the beacon of progress becomes dimmed. Paradoxically, it is in our residual flatland of actually existing consumerism that history may no longer be a burden, and it may even raise us above the eternal present of commodification.

The reconsideration of the past appears to be an even more urgent task outside the mostly pacified West, where

6 'I pittori ci hanno sempre mostrato cose e persone poste davanti a noi', ibid.

7 ' $[$ I $l$ moto e la luce distruggono la materialità dei corpi'. In Pittura Futurista. Il Manifesto Tecnico. 
the creeping Third World War does not stop claiming its toll of humans and things. From the perspective of this other world, the Western condition of perpetual economic struggle (and its promise of social mobility) is a mirage of safety and plenty. Western standards - even in their current combination of civil peace and pervasive economic war - are assumed as the reference condition and the normative background for the tribunals that have been assessing large-scale traumatic events and circumstances, such as South African apartheid and the Rwandan massacres. These variously horrifying exceptions are evaluated against Western or Westernised rules, which conjoin economic conflict and political peace.

It is then not surprising that the most relevant attempt at dealing with past traumatic social events was conducted by the 1995 South African Truth and Reconciliation Commission, a name that reveals both Western philosophical and theological legacies. Actually, as early as in 1990, Chilean president and Christian Democrat leader Patricio Aylwin established an investigative body, which was defined as Comisión Nacional de Verdad y Reconciliación, National Commission of Truth and Reconciliation. The commission reported on the horrific crimes committed under the military dictatorship led by General Augusto Pinochet between 1973 and 1990. ${ }^{8}$

${ }^{8}$ By the irony of history (or one of its bad jokes) it was the same Patricio Aylwin who said in an interview with The Washington Post on August 26, 1973 (sixteen days before the military coup) that if he had to choose between 'a Marxist dictatorship and a dictatorship of our military, [he] would choose the latter' 
In the case of South Africa, the Anglican archbishop Desmond Tutu, who was the main inspirer and chairperson of the commission, insisted on the closeness of the commission's guiding principles to Ubuntu ${ }^{9}$ the African sense of human interconnectedness. Be that as it may, the notion of reconciliation has a distinctively Christian overtone, which harks back to the foundational text of Christianity, Paul's letter to the Romans.

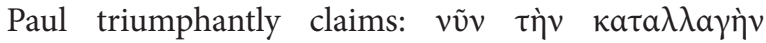

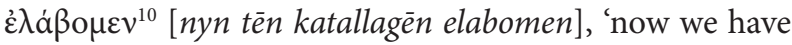
received reconciliation', as the death of Jesus overcame the long postlapsarian enmity between humans and god. In this context, truth is identified with the word of god, and even with god himself, whom, in the person of Jesus, John

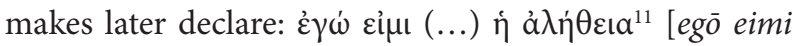
(...) he alètheia], 'I am the truth'.

Of course, truth is no longer construed as a divine person, at least not in its current judicial version. And yet, truth continues to share its transcendent quality with its Johannine personification. In the words of Tutu, truth is concealed, and its acknowledgement requires it to be unearthed; truth not only must come out, but it would prevail. $^{12}$

9 'One of the sayings in our country is Ubuntu - the essence of being human. Ubuntu speaks particularly about the fact that you can't exist as a human being in isolation. It speaks about our interconnectedness.' Desmond Tutu, 2008. Ubuntu Women Institute USA (UWIU) with SSIWEL as its first South Sudan Project, http://www. ssiwel.org (accessed 20 April 2011)

10 Romans 5.11 (Nestle-Aland).

11 John 14.6 (Nestle-Aland).

12 [T] his is a moral universe and truth will out.' In Desmond Tutu, No Future Without Forgiveness (New York: Doubleday, 1999), 87. 
One may observe that all the previous expressions show no distinctive theological features, and that they are instead commonplaces: apart from Tutu's optimistic and teleological claim of the eventual prevalence of truth, the latter's independence from subjective constructions is widely acknowledged. For example, the Oxford English Dictionary defines truth both as '[s] omething that conforms with fact or reality, ${ }^{13}$ and this very conformity.

If compared with the previous Johannine statement, OED's painstaking mapping of English language appears to register a double substitution: truth is no longer identical to the divinity, but it conforms to reality. Whilst the replacement of god with reality seems to confirm the modern claims of secularisation, the notion of truth as conformity is a restatement of a Scholastic assumption.

In the thirteenth century, the Dominican friar Aquinas quotes Isaac Israeli's definition of truth as 'adaequatio rei et intellectus, ${ }^{\prime 14}$ conformity of things and intellect. More recently, this correspondence is embraced by Bertrand Russell ${ }^{15}$ as constitutive of truth, ${ }^{16}$ and it is still popular

13 '[T]ruth, n. and adv. (and int.).' OED Online. Oxford University Press, March 2016.

14 Thomae de Aquino (Thomas Aquinas), Summa Theologice, Pars 1, Quaestio 16, Articulus 2, http://www.corpusthomisticum.org/ sth1015.html (accessed 11 May 2016). The original statement has not yet been located in Israeli's work.

15 Bertrand Russell, 'On the nature of truth and falsehood' in id., Philosophical Essays (New York: Simon and Schuster: 1910).

${ }^{16}$ Whilst this approach was supposed to derive from Plato and Aristotle, it probably stemmed from Plotinus' request for the eye to be sun-like in order to see the sun (Enneads 1.6.9.31-32), which in turn found a more abstract expression in Proclus' definition of truth as $\dot{\varepsilon} \varphi \alpha \rho \mu о \gamma \eta \dot{~[e p h a r m o g e ̄], ~ a g r e e m e n t ~ o r ~ a d j u s t m e n t ~ b e t w e e n ~}$ knower and the known (In Tim. 2.287.1). Epharmogē is already set 
with English speaking philosophers, ${ }^{17}$ whose belief in this regard seems generally pretty much in line with the wider language use, provided that such use conforms to its representation by the OED.

However, from the specific angle of truth and reconciliation commissions, the notion of truth is concerned with the re-evaluation of past actions and events: hence, it may be worth briefly considering the involvement of Western historical investigations with truth.

In the sixth century BCE, Hecatæus ushers in Western historical discourse with a declaration of disbelief in Greek stories ${ }^{18}$ : however, neither he nor most subsequent historians base their claim to validity on the direct appeal to the notion of historical truth. For some twentyfour centuries, the work of the historian remains $\tau \tilde{\omega} v$

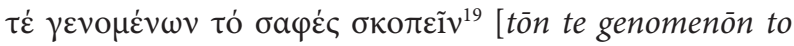
saphes skopein], 'to investigate the certainty of the events'

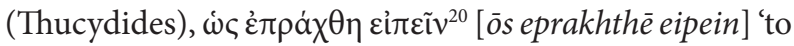
tell how things happened' (Lucian), and to show the past

as the final existential task in Porphyry's compilation of Plotinus' Enneads (6.9.11.25).

17 See, for example, the 2009 PhilPapers Survey taken by 3226 respondents (nearly $70 \%$ of them from English-speaking countries), including 1803 philosophy faculty members and/or $\mathrm{PhDs}$ and 829 philosophy graduate students. An impressive $50.8 \%$ of the respondents indicated their preference for a correspondence theory of truth. In David Bourget and David J. Chalmers, 'What Do Philosophers Believe?', Philosophical Studies 170, no. 3 (2014): 465-500.

18 'Thus speaks Hecatæus of Miletus: I write what follows as it seems to me to be true; for the logoi of the Greeks are, as it seems to me, many and ridiculous.' In Early Greek Mythography, ed. Robert L. Fowler (Oxford: Oxford University Press, 2000), Hecatæus fr. 1.

19 Thucydides 1.22.5.

${ }^{20}$ Lucian of Samosata, Quomodo historia scribenda sit 39. 
'wie es eigentlich gewesen, ${ }^{21}$ 'how it really was' (Ranke). Twentieth-century historians not only generally continue to keep the philosophical constructions of the notion of truth at arm's length, but, as in the case of Michel Foucault, plainly reject historical universals in general: and during the last forty years, more and more historians (Jenkins, Munslow, Southgate, Bunzl, and McCullagh among others) are embracing their inevitably perspectival construction of the past.

Historians' acknowledgement of their perspectival (a visual metaphor, again) relation with past events not only demands more sophisticated criteria for assessing historiographical constructions, but it also resonates with some juridical constructions of specifically legal truth. For instance, Hans Kelsen grounds this specificity on the production of legal facts as a result of legal ascertainment, which 'replaces the fact in itself that in nonjuristic thinking is the condition for the coercive act. ${ }^{22}$

More recently, Jack Balkin is adamant in advocating the productive character of law: 'law creates truth - it makes things true as a matter of law. It makes things true in the eyes of the law. ${ }^{23}$ Here the boldness of Balkin's first statement is somewhat defused by his further specifications,

${ }^{21}$ Leopold von Ranke, 'Preface: Histories of the Latin and Germanic Nations from 1494-1514', in The Varieties of History: From Voltaire to the Present, ed. Fritz Stern (New York: Meridian Books, 1956), 57.

22 Hans Kelsen, Pure Theory of Law, trans. Max Knight (Berkeley: University of California Press, 1967), 240.

${ }^{23}$ Jack M. Balkin, 'The Proliferation of Legal Truth', Harvard Journal of Law and Public Policy 26, no. 1 (2003): 6. http://www.yale.edu/ lawweb/jbalkin/articles/proliferationoflegaltruth1.pdf (accessed 11 April 2016). 
which also recur to a reassuring metaphor of the old, namely, the eyes of the law. ${ }^{24}$ However, by hinting to truth as a visual effect, Balkin subordinates both truth and true things to a specific perspective, which, mutatis mutandis, may appear to evoke Futurist contentions.

Moreover, in Balkin's sentence the word 'things' may well be understood in an extended sense, as legal constructions also legally define the truth of legal subjectivities: for example, both in Chile and South Africa, different legal approaches can shape the apparently same subject as either a patriot defending his country from the contagion of communism with all available means, or a brutal and insensitive torturer and murderer.

It is not by chance that these alternative subjectivations echo the bifurcation between the prosecution and defence arguments at the Nuremberg trials ${ }^{25}$ (and in some way also the Eichmann trial in Jerusalem). Jean-François Lyotard evokes this lack of common ground by recovering the French legal term differénd, ${ }^{26}$ which defines a case of conflict that cannot be equitably resolved for lack of an encompassing rule of judgement.

${ }^{24}$ The OED dates the first written occurrence of the phrase 'in the eye of the lawe' to 1538. In 'eye', OED Online. Oxford University Press, March 2017.

25 Probably, the only commonality between all the parts represented by the prosecution and the defence was the perpetration of the same war crime of mass murder by aerial bombing, which was prudently left out of the list of accusations.

${ }^{26}$ See Jean-François Lyotard, Le Différend (Paris: Éditions de Minuit, 1983); Eng. trans. id., The Differend: Phrases in Dispute, trans. Georges Van Den Abbeele. (Minneapolis: University of Minnesota Press, 1988). 
Tutu describes the Truth and Reconciliation Commission as a third way between the Nuremberg trials and blanket amnesty (or national amnesia) ${ }^{27}$ : amnesty is offered to the perpetrator in exchange for truth, provided that the applicant makes 'full disclosure of all of the facts relevant to the incident in question. ${ }^{28}$

The very wording of the Commission remarks how the access to past events is to be realised as the removal of the obstacles to the unobstructed view of the past itself: the current use of the term 'disclosure' is a later ${ }^{29}$ figurate sense of the literal action of unlocking, and it well describes the sharing of memories otherwise confined within the perpetrators.

Moreover, the exchange of disclosure for amnesty implies some kind of forgiveness on the part of the victims, generally in the person of their relatives and friends: yet, inasmuch as having Ubuntu means participating in a greater whole, to forgive is not just to be altruistic, but it is the best form of self-interest. ${ }^{30}$

Here, African and Christian idealisations clearly overlap, and yet, they may help in achieving the practical task of emotional closure, which the mother of a victim also describes as a double restitution: 'he [the murderer]

27 Tutu, No Future Without Forgiveness, 30.

28 Truth and Reconciliation Commission, Truth and Reconciliation Commission of South Africa Report, vol. 6 (Cape Town: Juta \& Co, 2003), 10.

29 The OED reports a 1525 written evidence of the figurate sense of the word 'disclosure', which appears in a text presumably composed in 1489. In 'disclosure', OED Online. Oxford University Press, March 2017.

30 Tutu, No Future Without Forgiveness, 31. 
becomes human again, this man, so that I, so that all of us get our humanity back.' ${ }^{31}$

Whilst this restitution risks being offered as a sort of Christian atonement and accepted instead as a profitable transaction, the possible specific imbalance of the exchange is transcended by the more general advantage of a shared political sense, which escapes the pincer of ideal principles and Realpolitik. It may even be argued that the transactional practice of these transitional measures immediately produces a shared political dimension.

Of course, not everyone may be inclined to forgive: as dryly stated by Charity Kondile - the mother of another victim - whilst Mandela and Tutu lead vindicated lives, nothing has changed in hers, therefore she cannot forgive. ${ }^{32}$ Indeed, Tutu himself describes both his sight of freedom coming and his involvement in the Truth and Reconciliation Commission as a 'spectacular vindication. ${ }^{33}$

However, and more important, both Kondile's and Tutu's considerations reveal a shift of focus from the past to the present: what appears to be at stake is not simply the recovery of traumatic events, but the role that their memory is allowed to play in the present. If this holds true, here truth is a misleading task, and its pursuit a mere verbal re-enactment of the Western theologico-philosophical

31 Cynthia Ngewu, mother of the murdered Christopher Piet, quoted in Antjie Krog, Country of My Skull (Johannesburg: Random House, 1998), 109.

${ }^{32}$ Charity Kondile, quoted in Antjie Krog, 'The Parable of the Bicycle', Mail \& Guardian, February 7, 1997, http://mg.co.za/article/199702-07-the-parable-of-the-bicycle (accessed 10 April, 2016).

33 Tutu, No Future Without Forgiveness, 287. 
legacy. Given the actual practices of the Commission, one may legitimately wonder whether the word 'truth' made it justice, and whether a more appropriate definition would instead have coupled reconciliation with memory. ${ }^{34}$

The substitute name of 'Memory and Reconciliation Commission' is not just a retrospective suggestion, as unfortunately the series of crimes against humanity ${ }^{35}$ gets longer and longer. If, as I hope, the example of the South African Commission will be further followed (as has already happened), a different definition of its scope may highlight the alternative between the pursuit of truth and the construction of memory. This alternative is not simply theoretical: whilst the emphasis on truth leaves the damaged ones the only choice of a more or less willing acceptance of the past, the active task of constructing memory in the present turns inner and outer transactions into self-empowering opportunities of intervention.

34 Tutu himself underlines the essential role of memory whilst describing the condition of the traumatised protagonist of the gripping play Death and the Maiden, in which the Chilean writer Ariel Dorfman stages the frightening re-emergence of the experience of politically justified terror, torture and rape. Tutu recalls that 'she was, in a real sense, her memory' (No Future Without Forgiveness, 30). The denial of her memory not only challenges her sense of self, but it also forces her to continue to embody this memory, which literally entraps her within her own body.

35 The legal notion of crimes against humanity was first defined in the paragraph 6(c) of the 1945 London Charter of the International Military Tribunal, which was meant as the legal basis for the Nuremberg trials. It was again by the irony of history that one of the three drafters of the Charter, Major-General Iona Nikitchenko, had presided over some of the infamous Moscow Trials between 1936 and 1938. Nikitchenko was also the Soviet Union's judge at the Nuremberg trials, and he was president for their opening session in Berlin. 
On the horizon of truth, the only socially constructive intervention of the damaged ones is an act of forgiveness: this is why a refusal such as Kondile's can only be either discarded as an incident in the process, or exalted as a symptom of the process' general failure. Facilitating the construction of memory would instead help redress resilience as a productive factor, both in inner and outer transactions. And whilst the creation of legal truth is at perpetual risk of clashing with similarly totalising ethical, religious, political, philosophical and scientific truths, the legal production of memory would easily find allies in any conceivable field, including fiction.

On the horizon of the construction of memory, fiction would be a tool as important as supposed non-fictional renderings of the past: and it may be even more effective in producing the visibility of the past itself. For example, when Swiss director Milo Rau staged in Moscow a re-enactment of the trial against the members of the punk-rock band Pussy Riot, ${ }^{36}$ the fictional tribunal produced a reconstruction of the facts, a discussion of the motivations, and a final judgement that shamed the previous proceedings of the official Russian court, which had charged the girls with a two-year sentence.

Rau's aptly named Moscow trials underline their rather farcical repetition of the homonymous tragedy, ${ }^{37}$ namely the 1936-38 series of trials, during which most surviving Bolshevik leaders pleaded guilty to hyperbolic crimes

\footnotetext{
36 1-3 March 2013, Sakharov Centre, Moscow.

${ }^{37}$ In The Eighteenth Brumaire of Louis Napoleon Marx famously described the vicissitudes of Luis Bonaparte as the farcical repetition of the tragedy of his uncle Napoleon.
} 
against the Soviet state. Regardless of the enormity of the accusations, the Moscow trials shared with the Nuremberg ones not only one of the judges, ${ }^{38}$ but also their predetermined finale. And it may be argued that also in the case of the Stalinist purges, their most relevant treatment was a fictional rendering, namely Arthur Koestler's 1940 novel Darkness at Noon.

However, Rau dealt with tragic events too, such as the Rwandan genocide and its catastrophic follow-up, the Congolese civil war. In the first case, the core instigating apparatus of the Rwandan massacres is given a fictional visibility on stage well beyond its actual visibility as a radio broadcasting station. ${ }^{39}$ The audience is allowed to watch the otherwise invisible source of the systematic outpouring of broadcasted hate speeches that prepare, prompt, guide and justify the bloodbath.

Rau's screenplay adds a surprising layer to the construction of the past: here the visibility of the events is even enhanced with respect to the actual experience of most direct participants, who were affected by the broadcasted hate speeches as merely acoustic phenomena.

Rau then tackled the terrifying Congolese sequel of the Rwandan disaster with a theatrical enactment, which was modelled on the 1966-67 Russell tribunal on Vietnam. His Congo Tribunal ${ }^{40}$ takes further a series of Interna-

\footnotetext{
38 See supra, note 35.

39 Hate Radio: The re-enactment of an RTLM genocide radio show was first performed on the 2 November 2011 at the Bregenz Kunsthaus.

40 The Congo Tribunal is a film and theatre production of Milo Rau and the International Institute of Political Murder (IIPM). It was staged in two sessions, 29 - 31 May 2015 in Bukavu, Collège Alfajiri (Eastern Congo), and 26 - 28 June 2015, Berlin, Sophiensaele.
} 
tional Criminal Court investigations and prosecutions, and it exposes local and international interests involved in the booming commodity trade in Eastern Congo. ${ }^{41}$

It would be difficult to trace a clear-cut boundary between fictional and non-fictional aspects in Rau's trials. However, these acts and their filmed versions iterate the visual representation of the deployment of juridical procedures in the construction of memory. By doing so, they perpetuate and amplify, so to speak, the embodiment of recollection with the sound of words and the image of the performing bodies.

Though in court the re-enactment of the past is supposed to rely on the cognitive function of words, the necessary embodiment of speech acts also inevitably expresses emotions and value judgements. These acoustic and visual components systematically exceed the merely factual rendering of the past as pursued by modern jurisprudence.

Of course, acoustic and visual effects are standard tools of forensic rhetoric: already Aristotle associates this specific kind of rhetorical speech with the investigation of the past that takes place in a trial. ${ }^{42}$ This forensic speech can only be either an accusation or a defence, ${ }^{43}$ because

${ }^{41}$ According to the press release (6), '[u]nlike the International Criminal Court or national courts, not only the local players, rebel leaders and low-rank soldiers will be held accountable before the Congo Tribunal but also their international accomplices who provided the supply lines for this atrocious civil war or prevented its cessation.' In http://www.the-congo-tribunal.com/wp-content/ uploads/2015/05/150424_Kongo-Tribunal_pess-kit.pd (accessed 13 May 2016).

42 Aristotle, Rhetoric 1.3.2.

43 Ibid., 1.3.3. 
according to Aristotle a trial is necessarily antagonistic. And yet, the acknowledgement of this basic antagonism, and its expression through the strategies of persuasion of forensic rhetoric, is at odds with the fundamental criterion of the just and the unjust, which the same Aristotle claims as the basis of court judgements.

This contradiction does not escape Aristotle's attention, but it is promptly solved: 'things that are true and things that are just are by nature superior to their opposites. ${ }^{34}$ Despite its naiveté, Aristotle's solution sounds obvious to us moderns, and it even smacks of Panglossian eudemonism, ${ }^{45}$ because Christianity endorsed its teleological perspective (and still endorses it, as in the case of Tutu).

The tension between the persuasive intentions of forensic rhetoric and the pursuing of truth is similarly erased whenever a superior necessity inspires the judgement. Such a tragic bottleneck is clearly revealed by the farcical enormity of the accusations (and self-accusations), as it happened in the various cases of medieval Inquisition, early modern witch hunts, and modern show trials: and regrettably, a similar logic informs even the best intentioned international courts.

We no longer need to appeal to Carl Schmitt to acknowledge the juridico-theological derivation of the strongly reductionist approach of modern legal systems. Forty years

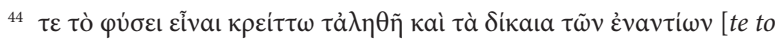
physei einai kreittō talēthē kai ta dikaia tōn enantiōn], ibid., 1.1.

45 Leibniz (and his well-intentioned Christian optimism) is notoriously and ferociously depicted by Voltaire in his novel Candide as the doctor Pangloss, who teaches that all is for the best in the best of all possible worlds.
} 
of generalised challenge to modernist biases have made us familiar with Schmitt's contention that the omnipotent lawgiver (and the omnipotent judge) re-enacts the omnipotent god in both Roman-derived and commonlaw jurisprudence. ${ }^{46}$ However, though the South African Truth and Reconciliation Commission partially restates this theological legacy with its pursuit of truth, by stressing reconciliation as a task it also acknowledges a plurality of subjectivating paths that cannot be immediately reduced to a common juridical logic.

I would like to be as optimistic as to construct some of the practices of the South African commission as an embryonic claim of a juridical logic of the differénd, which would be understood as the general norm of juridical practices rather than their exception. This reversal would imply that an encompassing juridical order may be produced as the ongoing result of negotiations between stakeholders, rather than as a postulation of principles, as according to the thousand-year tradition of juridical theology. ${ }^{47}$

Of course, such a de facto pluralism of values and practices is still a long way from obtaining a de jure recognition. In the meantime, we may well begin not only to reclaim our inherited Aristotelian juridical assessment of the past, but also to reframe it as the contribution of

${ }^{46}$ See Carl Schmitt, Political Theology: Four Chapters on the Concept of Sovereignty, trans. George Schwab (Cambridge, Mass.: MIT Press, 1985).

${ }^{47} \mathrm{I}$ argued for the significance of the notion of juridical theology in my essay 'Mystical Bodies and Bodies of Law: On Juridical Theology and the (Re)Foundations of the West', in Fables of the Law, eds. Daniela Carpi and Marett Leiboff (Berlin: De Gruyter, 2016). 
juridical practices to the construction of memory in the present. This double shift in time and scope would allow us to immediately recast past and present juridical practices.

It may be objected that a juridical reconstruction of memory requires an already established encompassing legal order: this order provides the legal framework for the activities of whatever ad hoc apparatus which is invested, generally after a political transformation, with the authority to reassess the past, in the perspective of reordering the present. And even in this case, the juridico-political intervention may have to endure the constraints imposed by resilient agents, such as, for example, the Chilean army or the South African economic complex.

The effect of these constraints is well depicted by the South African parable of the bicycle. As reported by Antjie Krog, ${ }^{48}$ a boy steals the bicycle of a neighbour, and after a year of consequential enmity, he invites the victim to reconcile. Nevertheless, when asked to return the stolen bicycle, he retorts that his offer is about reconciliation and not bicycles.

One may expect that, just like the South African boy, not many perpetrators would be willing to talk about bicycles, as it were. Worse than that, the very bicycle is but a euphemistic representation of wrongs that unfortunately go well beyond the appropriation or the destruction of objects. And unfortunately, humans cannot afford the luxury of waiting for an epochal transition that will let emerge a new historical sense: the human agenda of

${ }^{48}$ Krog, 'The Parable of the Bicycle.' 
survivors is dictated by the mere urgency of life, which often, to quote Brassens, 'is their only luxury.' ${ }^{49}$

The construction of memory is needed precisely to engage at once with oneself and the others in the present. This need is powerfully expressed by the protagonist of Joshua Oppenheimer's feature film The Look of Silence, which calls into question both notions of cinematographic representation and historical revisitation. In the movie, Adi Rukun plays himself and performs his actual conversations with those responsible for his brother's death.

Such conversations make the audience aware of the alarming fact that the killing of Adi's brother was not an isolated act of violence, but it was part of a huge carnage, which in 1965 and 1966 involved a large portion of the Indonesian population. An estimated minimum of a halfmillion people were massacred with the collaboration of the army in pogroms operated by paramilitary forces, which were instructed to prevent an alleged communist uprising.

To describe Adi's endeavour as a search for truth would be misleading: he is looking for more than something as impersonal as truth, ${ }^{50}$ and he is consequently rewarded, at times, with more than a mere reconstruction of the past. Adi is battling the apparent impossibility to share

49 'La vie est à peu près leur seul luxe ici-bas', life is more or less their only luxury down here. In Georges Brassens, 'Mourir pour des idées' (To Die for Ideas), Fernande (1972) Philips 6332116.

50 The divergence between the relational priority of Adi's quest and the abstract appeal to truth, as enacted by the director who is dismayed by the reiteration of denial, is staged in the cinematographically daring final scene. 
his present with his brother's unprosecuted murderers, the surviving bystanders, the other victims' relatives, and his brother's memory.

The theological vocabulary of truth and justice is simply unable to address Adi's conundrum, which is steeped in his relationship with himself and the others. And whilst Adi may seem only to dangerously confront the still influential perpetrators, he actually tries to engage them in a dialogue that at once makes room again for his brother (and for his murdered fellows), and repositions his interlocutors. ${ }^{51}$

Moreover, whilst the fictional re-enactment of the act of killing $^{52}$ for the sake of explication seems just to put the perpetrators again at centre stage, paradoxically it instead makes the killed ones re-emerge, first as mere human bodies, and then as human beings. The killing is re-enacted in the present without the cover of the dehumanising strategy that in the past turned the victims into a less-than-human source of danger: hence, the reappearance of the victims as human beings is now embodied by the perpetrators themselves, whose disconcert becomes sometimes visible.

According to Oppenheimer, visibility - in the literal sense - is not only a powerful aspect of his cinematic involvement with the Indonesian genocide, but also of

51 As Oppenheimer himself remarks, Adi's gentle offer of dialogue is only minimally successful, because reconciliation cannot be achieved on a personal basis, but it has to become a political process.

52 Oppenheimer mostly devoted his previous movie, The Act of Killing, to this re-enactment, albeit with a surreal twist. To underline the link between his two works, Oppenheimer presents them as a diptych. 
film in general, which can make visible the stories that constitute our identity. ${ }^{53}$ Once made visible, these stories can be acted upon again, and indeed they have to be. For example, the visibility of the act of killing, however fictional, inevitably exposes it to the considerations of the viewers, be they perpetrators, bystanders, victims' relatives or simply newcomers.

In general, cinematographic ${ }^{54}$ performances that reenact the past do construct memory by giving the past visibility in the present. More than that, all cinema, regardless of its content, produces memories through audio-visual synaesthesis: and inasmuch as these memories become part of our experience and reshape our horizon, cinema realises on a mass scale the Futurist program of a visual recasting of reality.

We may compare this cinematic ${ }^{55}$ feat with another construction of memory, namely the juridical assessment of the past. I have already argued that, at least with regard to forensic rhetoric, the legal re-enactment of the past is not limited to a merely verbal exercise, because it entails the embodiment of the spoken word on the part of the lawyer. However, even if, in truly modernist fashion, we were to deem as negligible the contribution of the literal visibility of performances to the legal construction of

${ }^{53}$ In the interview 10 Questions for Joshua Oppenheimer, https://www. youtube.com/watch? $\mathrm{v}=$ MnerL5WBB2M (accessed 3 May, 2016).

54 Of course, written narrations and theatrical representations also reenact the past and construct memory, but they cannot match the iterative mimetic ability of cinematographic fictions.

${ }^{55}$ Here I am also exploiting the old form of the term 'kinematic', which in English retains the sense of motion of its Greek source

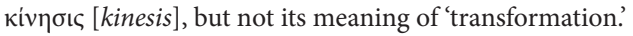


memory, the mere evocative power of the lawyer's speech acts would share with literature at large the effect of metaphorical visibility produced by words.

It may be observed that literary texts, unlike legal ones, do not necessarily owe allegiance to their outside, ${ }^{56}$ that is, the referent in the world, be it past or present: in the literary realm, Israeli, Aquinas and Russell's notion of adaequatio would be as inadequate as simplistic, because literature is not necessarily bound to reproduce in words the world. On the contrary, as the very word 'fiction' reminds us, literary texts are also allowed to produce fictive, that is, non-existent characters, occurrences and worlds. Of course, within this realm, a realistic representation of the world is not at all excluded, but it is just an instance of a wider universe of possibilities.

The range of legal constructions of the past may be ranked somewhere in between the kaleidoscopic array of literary productions and the limited representations of the narrow world of philosophical realism. Legal practices generate a metaphorical visibility of the past that may be better compared to the similar visualisations of the past that are put forth by the historians. This closeness to

${ }^{56}$ Borrowing Derridean terms, we may conceive of the outside-text (that is, the alleged absolutely objective referent of the text: for example, the past, nature, facts, or god) as an effect of intertextual connections: the more the intertextual links multiply, the more the perception of their role in the construction of their common objects dims, and the more these common objects acquire the objective character of outside-text. Paradoxically, the efficacy of theoretical production is testified by the extent to which its products make themselves autonomous, so to speak: its success thus coincides with its self-erasure. One may wonder whether it is possible to construct a memory that is not subjected to this dynamic of self-effacing success. 
historical evocations is even more evident when a wider legal understanding of the past is required to achieve some kind of reconciliation, which makes visible, such as in Adi's conundrum, both the living and the dead.

In Western culture, the visibility of the dead has been long entrusted to historians, who since Hecatæus have competed for this role with the poets. ${ }^{57}$ In more colourful terms, despite the later fierce competition of priests, historians are nowadays securely in charge of communicating with the dead. More precisely, historians are not requested to speak to the dead, but rather to make the dead speak. This is not a ventriloquist's trick, because historians do engage with the deeds of the dead through things.

An immense and expanding hybrid network links the dead, the things, their living orderers and variously integrating, overlapping and even conflicting ordering techniques. This network includes a bewildering amount and variety of internal connections, which also perform as cross checks. The vastness and the complexity of the network ridicule the claims of objective historical truth as presumptuous shortcuts.

Regardless of its metaphysical implications, the simplistic notion of objective historical truth performs as a fig-leaf that covers the obscene reduction of the work of

57 This historical competition (which is also retrospectively construed by Plato as a feud between philosophers and poets) is generally recast as the passage from mythos to logos, which is the foundational narrative of Western thought. For a different reading, see Robert L. Fowler, 'Thoughts on myth and religion in early Greek historiography', Minerva 22 (2009): 21-39. 
the historian to the putting together of a jigsaw puzzle. On the contrary, we may well recover Balkin's contention about the making of legal truth, and say that historians as well make things true in the eyes of history. And yet, in the light of our previous path, and also considering the powerful surge of cinematographic ${ }^{58}$ constructions of memory, a single past may not be enough. In particular, if the engagement with the past is part of a process of reconciliation, we may wonder whether it would be enough for historians and legal scholars to produce truth - in the singular - in the eyes of history and law respectively.

As we saw, the juridical contribution to a reconciliation process appears to require more than a single truth. For sure, this requirement may be addressed in fairly different ways. At the risk of oversimplifying, in the language of conflict, reconciliation may be either understood as a mere tactical expedient for dealing with the temporary obstacle of some irreducible other, or it may be construed as a strategic approach to face previous conflicts and try preventing future ones.

This strategic construction of reconciliation may strike a middle path between the mere plurality of the Aristotelian antagonistic legal agents, and the pre-established convergence towards the Aristotelian telos, the Christian divine person, and their various modern omnipotent avatars. In this perspective, we may envisage a double task for legal activities: on the one hand, legal actors at large may relinquish as untenable the claim to the monopoly

${ }^{58}$ Here I include in the category of 'cinematographic' not only movies, but also television and new media video shots. 
of memory as a single legal truth, and they may work instead to produce the visibility of the plurality of the past; on the other hand, legal experts may then facilitate the negotiation between the representatives of this plurality in the present.

Whilst such a twofold approach could immediately inform the practices of transitional justice, it may affect an even wider legal horizon if, following Kathleen Daly, we would construct restorative justice as a mechanism of meetings of stakeholders, facilitated by a third party according to 'rules and procedures that align with what is appropriate in the context of the crime, dispute, or bounded conflict. ${ }^{59}$

However, in both contexts of transitional and restorative justice, the appeal to truth would be likely to resurface over and over during reconciliation processes: it would then be for the facilitating body to help assess whether the authority of truth is used to silence alternative positions, or to make previously invisible stances come to light.

It would be worth clarifying the nature of this emergence to light, though. Since Plato's invention of the ideal dimension, which he fabricated with words borrowed from the lexicon of vision, the depiction of visibility as the disclosure of truth has been endlessly reiterated in Western thought. For example, I recalled how the South African Truth and Reconciliation Commission particularly focused on the full disclosure of facts. And yet, the

59 Kathleen Daly, 'What is Restorative Justice? Fresh Answers to a Vexed Question', Victims \& Offenders: An International Journal of Evidence-based Research, Policy, and Practice, Special Issue: The Future of Restorative Justice 11, no 1 (2016): 21. 
visibility of the past well exceeds a single dimension ranging from emptiness to fullness. On the contrary, it may be time, at last, to take responsibility for what we make visible. It would be for each of us to acknowledge that producing the visibility of the past means also producing the past itself as memory, or better, as memories, in the plural: and as different practices produce different memories, it would be for the law to help this plurality not only to take shape, but also to coexist.

\section{References}

10 Questions for Joshua Oppenheimer. Accessed 3 May 2016. https://www.youtube.com/watch?v=MnerL5WBB2M

Baldissone, Riccardo. 'Mystical Bodies and Bodies of Law: On Juridical Theology and the (Re)Foundations of the West'. In Fables of the Law, edited by Daniela Carpi and Marett Leiboff. Berlin: De Gruyter, 2016.

Balkin, Jack M. 'The Proliferation of Legal Truth'. Harvard Journal of Law and Public Policy 26, no. 1 (2003): 6. Accessed 11 April 2016 http://www.yale.edu/lawweb/jbalkin/articles/ proliferationoflegaltruth1.pdf

Balla, Giacomo and Fortunato Depero. Ricostruzione futurista dell'universo. Milano: Direzione del Movimento Futurista, 1915. Blake, William. The Complete Poetry and Prose of William Blake, edited by D. V. Erdman. Berkeley: University of California Press, 2008.

Boccioni, Umberto et al. Pittura Futurista. Il Manifesto Tecnico. Milano: Uffici di Poesia, 1910.

Boltanski, Christian. 'An Interview with Georgia Marsh'. In Reconstitution, Exhibit Catalogue, Christian Boltanski. London: Whitechapel Art Gallery, 1990.

Bourget, David. and David J. Chalmers. 'What Do Philosophers Believe?'. Philosophical Studies 170, no. 3 (2014): 465-500. 
Brassens, Georges. 'Mourir pour des idées'. Fernande (1972) Philips 6332, 116.

Daly, Kathleen. 'What is Restorative Justice? Fresh Answers to a Vexed Question' Victims \& Offenders: An International Journal of Evidence-based Research, Policy, and Practice, Special Issue: The Future of Restorative Justice 11, no. 1 (2016): 21.

de Aquino, Thomae. Summa Theologioe, Pars 1, Quaestio 16, Articulus 2. Accessed 11 May 2016 http://www.corpusthomisticum.org/sth1015.html

Fowler, Robert L., eds. Early Greek Mythography. Oxford: Oxford University Press, 2000.

Fowler, Robert L. 'Thoughts on myth and religion in early Greek historiography’. Minerva 22 (2009): 21-39.

Joyce, James. Ulysses. Oxford: Oxford University Press, 2008.

Kelsen, Hans. Pure Theory of Law. Translated by Max Knight. Berkeley: University of California Press, 1967.

Krog, Antjie. 'The Parable of the Bicycle'. Mail \& Guardian, February 7, 1997. Accessed 10 April, 2016 http://mg.co.za/articl e/1997-02-07-the-parable-of-the-bicycle

Krog, Antjie. Country of My Skull. Johannesburg: Random House, 1998.

Laforgue, Jules. Mélanges Posthumes. Paris: Mercure de France, 1903.

Lyotard, Jean-François. Le Différend. Paris: Éditions de Minuit, 1983.

Marinetti, Filippo. Zang Tumb Tumb. Milano: Edizioni Futuriste di Poesia, 1914.

OED Online. Oxford University Press, March 2016.

Russell, Bertrand. Philosophical Essays. New York: Simon and Schuster: 1910.

Schmitt, Carl. Political Theology: Four Chapters on the Concept of Sovereignty. Translated by George Schwab. Cambridge, Mass.: MIT Press, 1985.

The Congo Tribunal. Accessed 13 May 2016 http://www.thecongo-tribunal.com/wp-content/uploads/2015/05/150424_ Kongo-Tribunal_pess-kit.pdf 
Truth and Reconciliation Commission. Truth and Reconciliation Commission of South Africa Report, vol. 6. Cape Town: Juta \& Co, 2003.

Tutu, Desmond. Ubuntu Women Institute USA (UWIU) with SSIWEL as its first South Sudan Project, (2008). Accessed 20 April 2011 http://www.ssiwel.org

Tutu, Desmond. No Future Without Forgiveness. New York: Doubleday, 1999.

von Ranke, Leopold. 'Preface: Histories of the Latin and Germanic Nations from 1494-1514'. In The Varieties of History: From Voltaire to the Present, edited by Fritz Stern. New York: Meridian Books, 1956. 